\title{
Effects of Volatile Components on Mixing State and Size Distribution of Individual Black Carbon \\ Aerosols
}

Aerosol and Air Quality Research

\section{OPEN ACCESS}

Received: January 25, 2022

Revised: March 3, 2022

Accepted: March 4, 2022

${ }^{*}$ Corresponding Author:

16110740006@fudan.edu.cn

Publisher:

Taiwan Association for Aerosol Research

ISSN: $1680-8584$ print

ISSN: 2071-1409 online

Copyright: The Author(s). This is an open access article distributed under the terms of the Creative Commons Attribution License (CC BY 4.0), which permits unrestricted use, distribution, and reproduction in any medium, provided the original author and source are cited.

\author{
Kangning $\mathrm{Li}^{1}$, XiaoFei Wang ${ }^{2}$, Xiaohui Lu ${ }^{2}$, Hong Chen ${ }^{2}$, Xin Yang ${ }^{3 *}$ \\ ${ }^{1}$ Ningxia Key Laboratory of Intelligent Sensing for the Desert Information, School of Physics and \\ Electronic-Electrical Engineering, Ningxia University, Yinchuan750021, China \\ ${ }^{2}$ Shanghai Key Laboratory of Atmospheric Particle Pollution and Prevention, Department of \\ Environmental Science and Engineering, Fudan University, Shanghai 200433, China \\ ${ }^{3}$ School of Environmental Science and Engineering, Southern University of Science and \\ Technology, Shenzhen 518055, China
}

\section{ABSTRACT}

In this study, the effects of different volatile components on the mixing state and size distribution of ambient individual black carbon (BC) aerosols were measured using thermodenudation with single-particle soot photometry and single-particle aerosol mass spectrometry from September 9 to September 27, 2018, in Shanghai, China. The volatility, chemical composition, size distribution, and core-shell structure of $\mathrm{BC}$ aerosol were also analysed. To understand the influence of heating temperature on the $\mathrm{BC}$ core-shell structure, the mixing state of ageing particles at room temperature $\left(25^{\circ} \mathrm{C}\right)$ and the mixing state of residual material heated to $150^{\circ} \mathrm{C}$ and $300^{\circ} \mathrm{C}$ were analysed. BC was internally mixed with secondary components, such as ammonium nitrate, ammonium sulphate, a small amount of sodium nitrate, potassium nitrate, sodium sulphate and potassium sulphate, and other nonvolatile components. At $300^{\circ} \mathrm{C}$, the secondary components with low volatility escaped, resulting in a thinner BC coating. However, several low-volatile non$\mathrm{BC}$ substances remained, namely organic species, potassium chloride, potassium nitrate, and other nonvolatile substances. The extremely strong photochemical reaction may have produced large amounts of secondary organic carbon on the BC surface in the afternoon, with the high temperature volatilising the whole particle. However, fresh BC particles emitted from traffic during morning rush hour had ultralow volatility, with relatively fewer low-volatile components on the surface.

Keywords: Black carbon, Mixing state, Size distributions, Volatility

\section{INTRODUCTION}

The rapid industrialisation and urbanisation in the past few decades have led to severe air pollution across China that has adversely affected people's lives and health (Zhang et al., 2015a; Lelieveld et al., 2020). Although research has demonstrated that air quality in China has improved considerably in recent years (Wang et al., 2018), adverse meteorological conditions, regional transport, heterogeneous reactions, and other factors have led to occasional extreme haze weather events, especially in spring and winter (Zhang et al., 2015b).

Black carbon $(\mathrm{BC})$ aerosol, one of the major contributors to positive radiative forcing and a key atmospheric light absorber, is produced from the incomplete combustion of wood and biomasses, such as crop residue and fossil fuels (Jayne et al., 2000; Bond et al., 2013). BC aerosol can be a carrier of coagulable species, and its morphology, size, chemical composition, and mixing state are influenced by physical adsorption and multiphase chemical reactions occurring on its surface (Zhang and Zhang, 2005). Several secondary components, such as nitrate and sulphate, can enhance 
the light absorption of BC particles through the lens effect (Wang et al., 2014a; Liu et al., 2015; Xie et al., 2019). In addition, the mixing state of BC particles influences BC's hydroscopicity, affecting its rate of wet deposition removal (Liu et al., 2013). An in-depth study of the mixing state of $B C$ is essential to understanding $B C^{\prime}$ 's influence on radiative forcing and global climate change (Liu et al., 2011; Wang et al., 2015; Cre and Krecl, 2016). In addition to BC particles in the air reducing visibility (Zhou et al., 2012; Wang et al., 2013a), direct inhalation of BC particles can lead to diseases of the blood vessels, heart, and respiratory system (Janssen et al., 2011; Healy et al., 2012), implicating $B C$ as a major air pollutant.

The mixing state of ambient $\mathrm{BC}$ (i.e., $\mathrm{BC}$ either emitted as pure $\mathrm{BC}$ or mixed with other inorganic components) is closely linked to its initial source (Chirico et al., 2010; Heringa et al., 2011). The particle size, chemical composition, and mixing state of $B C$ in the atmosphere are complex and dynamic, and $\mathrm{BC}$ aerosol particles can condense on surfaces through water vapour and form a surface coating composed of secondary components, such as sulphate, nitrate, and organic carbon after ageing in the atmosphere (Pratt et al., 2011). These coating components lead to changes in particle size, chemical composition, mixing state, hygroscopicity, and optical properties at the single-particle level, which hinders the traceability of such aerosols (Lelieveld et al., 2002; Kanakidou et al., 2005; Adler et al., 2011).

A number of studies on BC have been conducted and they are mainly focused on BC mass concentration, chemical characteristics and optical properties (Wu et al., 2017; Meng et al., 2016). Wang et al. (2019) studied the BC particles in Beijing and the result revealed that the secondary components, such as nitrate, sulfate and organic components, have obvious influence on the $\mathrm{BC}$ properties, significant for particles with larger $\mathrm{BC}$ core and thicker coating. Further time-resolved investigation on $\mathrm{BC}$ particles indicated that the more polluted periods, the greater contribution of secondary components, and $\mathrm{BC}$ with thicker coating is more likely to associate with secondary components, indicating that chemical ageing plays an important role in $\mathrm{BC}$ pollution in Beijing (Wang et al., 2019). Wang et al. (2021) investigated the optical properties of BC models (including bare, parted coated and embedded BC particles) constructed by ElectronMicroscope-to-BC-Simulation (EMBS). The multiphase processes, condensation and coagulation of coating materials influenced the coating thickness and mixing state of $B C$ particles in the atmosphere. And the mixing structure between BC coating and its core, coating shape and morphology of $\mathrm{BC}$ core directly influence the absorption enhancement of $\mathrm{BC}$ particles (Wang et al., 2021).

Volatility, a key physical property of aerosol, is defined by how readily condensed matter vaporises (Jonsson et al., 2007). Aerosol volatility is evaluated based on the evaporation of its different chemical components at characteristic temperatures. A semivolatile component can be vaporised at its boiling point, vapor pressure, and enthalpy of vaporisation, leaving a residual core with low volatility (Johnson et al., 2004; Engler et al., 2007). Typically, volatility is studied using thermo-denudation (TD) in conjunction with other chemical composition measurements. For example, May et al. (2012) measured the volatility distribution of single-component aerosol through TD in combination with TD-gas chromatography/mass spectrometry (GC/MS). TD was also coupled with aerosol time of flight mass spectrometry (ATOFMS) to determine the chemically resolved volatility of organic aerosols (Huffman et al., 2009). TD was also combined with ATOFMS for the study of aerosol sizes and chemical compositions (Pratt et al., 2009; Pratt and Prather, 2009). Zhai et al. (2015) researched the size, chemical composition, and mixing state of single particles using TD with single-particle aerosol mass spectrometry (SPAMS). However, these studies have not included $\mathrm{BC}$ aerosol with extremely low volatility with a refractory core.

\section{METHODS}

In this study, a method using SPAMS and single-particle soot photometry (SP2) downstream of TD was developed to simultaneously measure the real-time size and mixing state of ambient individual BC aerosols. The experiment was conducted in the urban area of Shanghai, a typical polluted mega-city in China. The residual components of aged BC particles at three temperatures were compared to understand the mixing state of $B C$ and its atmospheric volatility. The effects of different volatile components on the particle size, chemical composition, and mixing state of BC 


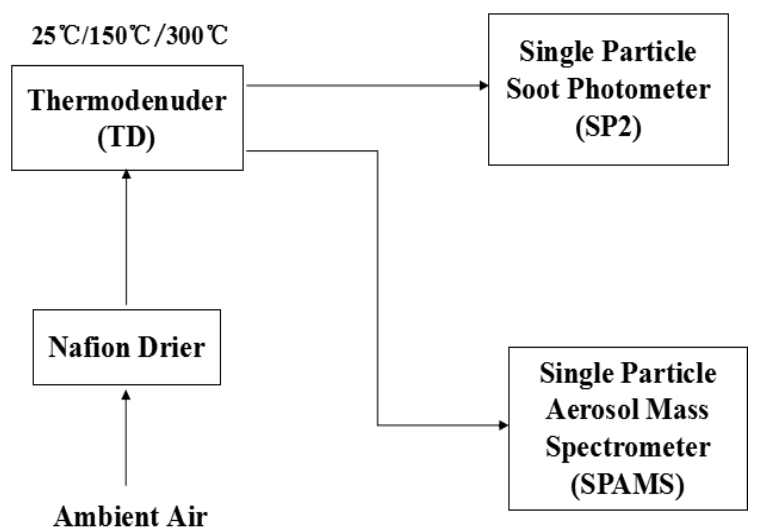

Fig. 1. Schematic of the experimental device.

were identified, which may provide insights into the effects of atmospheric processes on the mixing state of $\mathrm{BC}$ particles.

\subsection{TD-SP2\&SPAMS System}

The effects of different volatile components on the mixing state and size distribution of single BC aerosols were determined using a custom-built thermo-denuder (TSI Model 3065) with a SP2\&SPAMS system (Fig. 1). SP2 (DMT, Boulder, CO, USA) was used downstream of TD to measure the mass and number distribution of $\mathrm{BC}$-containing particles as a function of TD temperatures, and most individual $\mathrm{BC}$-containing aerosols were examined at different heating temperatures. The volatility property of BC surfaces is closely linked to mixing states. SPAMS (Hexin Analytical Instrument Co., Ltd.) was used in parallel with SP2 to determine the chemical composition of BCcontaining aerosols heated using TD.

The thermo-denuder comprised a 0.04-m-long metal heating tube and a 0.07-m-long activated carbon adsorption tube (Huffman et al., 2008). First, the aerosol was transmitted into the metal heating tube at a preset temperature. The volatile component encased on the surface of internally mixed particles volatilised and escaped, entering the activated carbon adsorbent in a gaseous form, which prevented its recombination with the particles after condensation. Vapourised gas phase components were absorbed by the activated carbon, and aerosols containing low-volatile components remained. The heating tube was subjected to three heating temperatures: $25^{\circ} \mathrm{C}$, $150^{\circ} \mathrm{C}$, and $300^{\circ} \mathrm{C}$. The aerosols were in the heating tube for approximately 10 seconds.

Ambient particles were added to the thermo-denuder at a rate of $130 \mathrm{~cm}^{3} \mathrm{~min}^{-1}$, with a $2.5 \mu \mathrm{m}$ cyclone impactor removing particles larger than $2.5 \mu \mathrm{m}$. After 1 hour, the BC concentration was measured using SP2. To prolong the experimental time without producing excessively large data sets, data were collected for every 100 particles. SPAMS was used in parallel with SP2 to determine the chemical composition of BC-containing particles. Detailed descriptions of the two detecting instruments and their operation procedures are available in the literature (Li et al., 2011; Gong et al., 2016). A schematic of the experimental device is displayed in Fig. 1.

TD was used to study particle volatility. Generally, volatile temperatures below $150^{\circ} \mathrm{C}$, between $150^{\circ} \mathrm{C}$ and $300^{\circ} \mathrm{C}$, and above $300^{\circ} \mathrm{C}$ are classified as temperatures for highly volatile, moderately volatile, and nonvolatile components, respectively (Ishizaka and Adhikari, 2003). According to the literature, the main compounds volatilising below $150^{\circ} \mathrm{C}$ are ammonium chloride, ammonium nitrate, formic acid, and acetic acid. The main compounds volatilising at $150^{\circ} \mathrm{C}-300^{\circ} \mathrm{C}$ are secondary organic carbon, ammonium sulphate, and ammonium bisulphate. The main compounds volatising above $300^{\circ} \mathrm{C}$ are potassium sulphate, potassium chloride, BC, and sea salt (Ishizaka and Adhikari, 2003). Thus, we set three temperatures in this experiment: $25^{\circ} \mathrm{C}, 150^{\circ} \mathrm{C}$, and $300^{\circ} \mathrm{C}$.

\subsection{Sampling}

The experiment was conducted from September 9 to September 27, 2018, using the TDSP2\&SPAMS system. The sampling site was on the sixth floor of the Department of Environmental Science and Engineering of the Jiangwan Campus of Fudan University $\left(31^{\circ} 20^{\prime} \mathrm{N}, 121^{\circ} 30^{\prime} \mathrm{E}\right), \mathrm{a}$ 


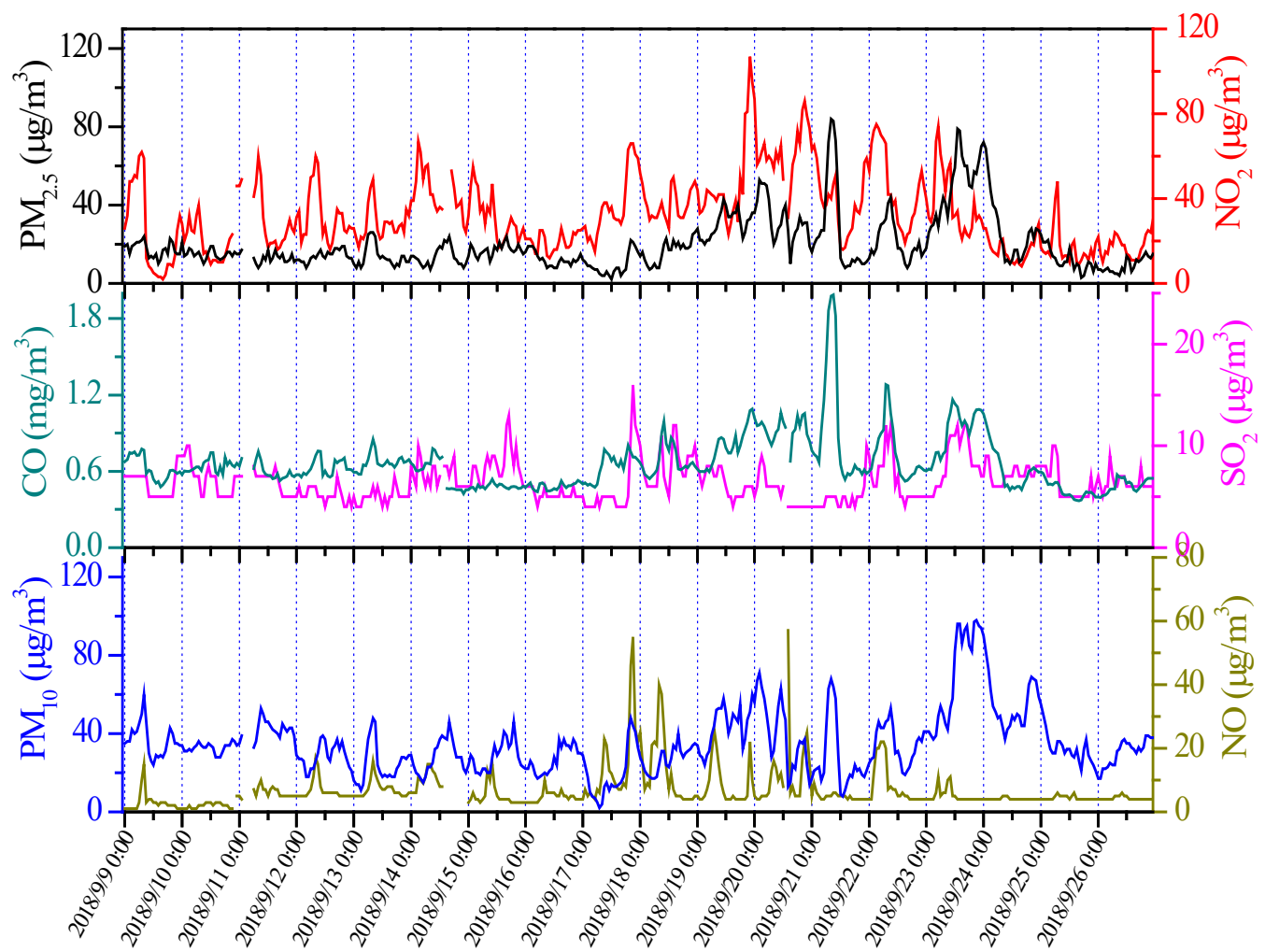

Fig. 2. Temporal profiles of $\mathrm{PM}_{2.5}, \mathrm{PM}_{10}$, and gaseous pollutants $\left(\mathrm{CO}, \mathrm{NO}_{\mathrm{x}}\right.$, and $\left.\mathrm{SO}_{2}\right)$ mass concentrations with 1-hour resolution

location considerably influenced by traffic emissions and human activity due to its vicinity to commercial and residential areas.

\subsection{Overview of Meteorology}

Temporal profiles of $\mathrm{PM}_{2.5}, \mathrm{PM}_{10}, \mathrm{NO}_{x}, \mathrm{SO}_{2}$, and $\mathrm{CO}$ concentrations during the observation period were obtained from the Shanghai Environmental Monitoring Center (Yangpu Station), which is located approximately $6 \mathrm{~km}$ from the sampling location. The air quality and meteorological information are displayed in Fig. 2. During the observation period, the mass concentration of $\mathrm{PM}_{2.5}$ peaked at 8:00 on September $21\left(79 \mu \mathrm{g} \mathrm{m}^{-3}\right)$, which was less than $80 \mu \mathrm{g} \mathrm{m}^{-3}$. The $\mathrm{PM}_{2.5}$ mass concentrations remained below $45 \mu \mathrm{g} \mathrm{m}^{-3}$ at all other times. The maximum $\mathrm{PM}_{10}$ concentration was $103 \mu \mathrm{g} \mathrm{m}^{-3}$ at 20:00 on September 23, indicating that air quality was higher during that period. The measured gaseous pollutants of the study period are presented in Fig. 2. During the sampling period, the mass concentrations of $\mathrm{CO}$ and NO varied from 0.369 to $1.988 \mathrm{mg} \mathrm{m}^{-3}$ and from 1.00 and $131.00 \mu \mathrm{g} \mathrm{m}^{-3}$, respectively; the average $\mathrm{CO}$ and $\mathrm{NO}$ concentrations were $0.66 \mathrm{mg} \mathrm{m}^{-3}$ and $7.11 \mu \mathrm{g} \mathrm{m}^{-3}$, respectively.

\section{RESULTS AND DISCUSSION}

\subsection{Diurnal Variation in BC Number Concentration and Proportion}

A thermo-denuder was connected with SPAMS and SP2; the automatic valve was set to change the temperature every 60 minutes to enable the study of the influence of different volatile components on the ambient $\mathrm{BC}$ mixing state. The thermo-denuder was set at three heating temperatures to measure changes in $\mathrm{BC}$ particle size and core-shell structure as well as chemical composition of volatile components before and after volatilisation.

The diurnal variation in the $\mathrm{BC}$ number fraction (i.e., the ratio of the $\mathrm{BC}$ number concentration to that of total particles at a given temperature) is presented in Figs. 3(a) and 3(c). Obvious peaks occurred at 8:00 and $18: 00$ at room temperature and $150^{\circ} \mathrm{C}$. This trend was more pronounced at 

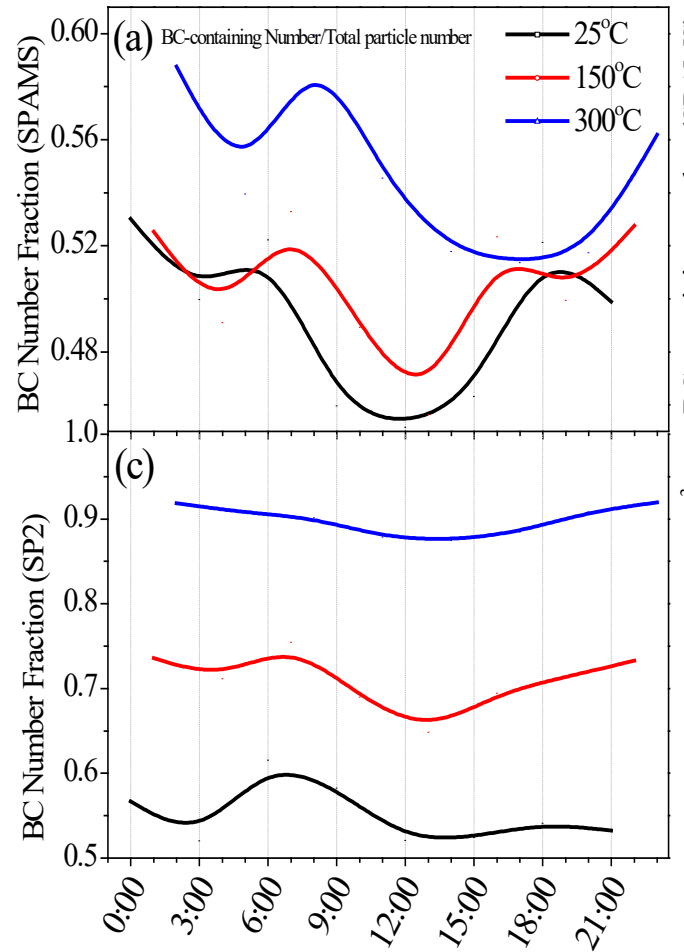
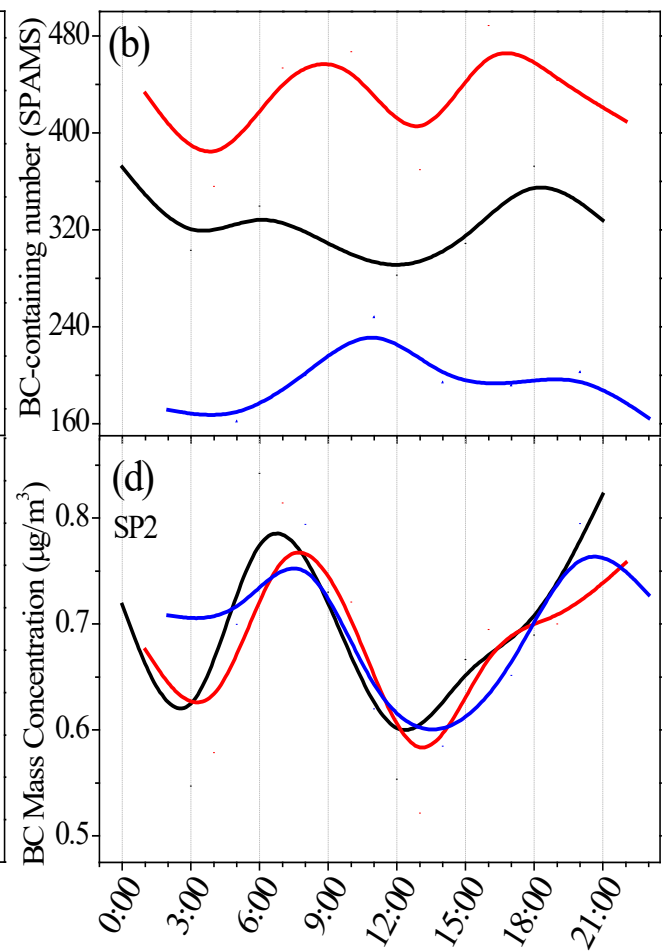

Fig. 3. Diurnal variation in $\mathrm{BC}$ number concentration and number fraction.

$25^{\circ} \mathrm{C}$, which is likely due to traffic emissions in the city. As indicated in Fig. 3(a), the BC number fraction (measured using SPAMS) increased considerably with the increase of the thermodenuder temperature. When $\mathrm{BC}$ was mixed with other secondary substances and the atmosphere contained numerous non-BC substances at room temperature, the $\mathrm{BC}$ number fraction was low. When the thermo-denuder heating temperature increased, volatile secondary substances volatilised and escaped, resulting in a decrease in the total particle number, although the $\mathrm{BC}$ number fraction increased. The $\mathrm{BC}$ number fraction was the highest at $300^{\circ} \mathrm{C}$, which was attributable to most non- $\mathrm{BC}$ particles having been volatilised and to the low volatility of $B C$ particles. Notably, the maximum $\mathrm{BC}$ number fraction was $60 \%$ at $300^{\circ} \mathrm{C}$, indicating that several low-volatile non-BC substances, such as secondary organic aerosols, potassium chloride, potassium nitrate, and other hydrophilic substances, remained, which is consistent with the findings of other studies (Wang et al., 2014b). Because of the collection efficiency of the instruments, the particle size was not limited in this experiment. As presented in Fig. 3(b), the number concentration of BC-containing particles was the lowest at $300^{\circ} \mathrm{C}$ and highest at $150^{\circ} \mathrm{C}$, which is mainly due to the diameter measuring efficiency of SPAMS. At $300^{\circ} \mathrm{C}$, volatile substances on the BC surface escaped, causing the overall BC size to sharply decrease and exceed the detection limit of SPAMS $(200 \mathrm{~nm})$. At $150^{\circ} \mathrm{C}$, surface volatilisation may cause some large BC to decrease in size; thus, these particles were within the efficient diameter measurement range of SPAMS $(500-700 \mathrm{~nm})$. Therefore, the number concentration of $\mathrm{BC}$-containing particles at the experimental temperature was significantly higher than that room temperature. The diurnal variation in the $\mathrm{BC}$ number concentration at $300^{\circ} \mathrm{C}$ was as follows: from 15:00 to 18:00, the concentration was significantly low, whereas from 9:00 to 12:00, the concentration was high, indicating that many low-volatile components mixed on the BC surface in the afternoon. Therefore, the extremely strong photochemical reaction likely produced secondary organic carbon coatings on the BC surface, and the high temperature volatised the entire particle. However, fresh $\mathrm{BC}$ particles emitted from traffic during morning rush hour have ultralow volatility, with fewer low-volatile components residing on the surface.

As presented in Figs. 3(c) and 3(d), the diurnal variation in the BC number fraction and BC mass concentrations was consistent with that identified using SPAMS. The BC number fraction increased with an increase in the heating temperature. When the thermo-denuder was heated to $300^{\circ} \mathrm{C}$, the $\mathrm{BC}$ number fraction was high as $90 \%$, which was significantly higher than the fractions obtained 
through SPAMS. This is likely because the tube diameters of the two instruments are different; SPAMS is mainly used to measure aerodynamic particle sizes between 200 and $1200 \mathrm{~nm}$, whereas SP2 is mainly used to measure optical particle sizes between 60 and $600 \mathrm{~nm}$. Because BC particles in the air are mainly smaller than $200 \mathrm{~nm}$ (Kondo et al., 2006), SPAMS underestimated the BC number concentration. Therefore, the $\mathrm{BC}$ number fraction measured using $\mathrm{SP} 2$ at $300^{\circ} \mathrm{C}$ was significantly higher than that measured using SPAMS.

The BC number concentration measured using SP2 exhibited obvious peaks in the morning and evening. However, no significant correlation was identified between the $\mathrm{BC}$ number concentration and temperature because the BC particles detected using SP2 contained refractory cores with low volatility, and heating caused only some of the coating components on the $\mathrm{BC}$ surface to volatilise; it did not affect $B C$ number concentrations. That is, the $B C$ number concentrations were identical at different temperatures, although the concentrations demonstrated clear diurnal variations, which may be caused by traffic emissions during rush hour (Dreher and Harley, 1998; Allen et al., 1999; Bhugwant et al., 2000). Therefore, although the BC number density was identical under different temperatures, diurnal variation occurred. Heating causes the coatings on the surface to volatilise but has no effect on the number of $\mathrm{BC}$ particles. According to the diurnal variation in the $\mathrm{BC}$ number fraction, the $\mathrm{BC}$ particle peak due to traffic emissions in the morning was significantly higher than the peak in the evening. From 12:00 to 15:00, the BC number fraction had a valley value, indicating that most $\mathrm{BC}$ particles were covered by low-volatile components or that much more non-BC particles were present in the atmosphere, which is related to the strong atmospheric chemical reactions that occur in the afternoon.

\subsection{BC Aerosol Classified Using SPAMS}

In this experiment, a total of 497,092 particles with positive and negative mass spectra were detected using SPAMS. Elemental carbon (EC) ion clusters detected using SPAMS are considered key markers of BC particles (Gong et al., 2016). In this study, using $C_{n}^{+/-}(n=1,2,3 \ldots)$ as the BC marker, $288,232 \mathrm{BC}$ particles were identified, accounting for $58.0 \%$ of the detected particles. Using adaptive resonance theory (ART-2a), BC particles were classified according to their mass spectra similarities (Song et al., 1999). As in other studies (Li et al., 2018; Spencer et al., 2007; Huang et al., 2013; Gong et al., 2016; Zhai et al., 2017; Li et al., 2018), the learning rate, vigilance factor, and iterations for the ART-2a algorithm were set to $0.05,0.85$, and 20 , respectively. Finally, all BC particles were manually divided into five types based on the similarity of the main components of the particles. These types were EC, ECOC, NaKEC, KEC, and Other. The average mass spectra and number fractions for each type are presented in Fig. S1 and Table S1, respectively.

The EC particles demonstrated clear EC ion clusters $\left(C_{n}^{+}\right.$and $\left.C_{n}^{-}, \mathrm{n}=1,2,3 \ldots\right)$ in both positive and negative ion mass spectrometry. The signal for the secondary components $\left({ }^{-97} \mathrm{HSO}_{4}{ }^{-},{ }^{-46} \mathrm{NO}_{2}{ }^{-}\right.$, and ${ }^{-62} \mathrm{NO}_{3}{ }^{-}$) was weak, indicating pure EC in the atmosphere that did not undergo ageing and newly emitted pure EC.

The ECOC particles mainly demonstrated EC ion clusters, and in the positive ion mass spectra, the clusters were mixed with organic carbon signals $\left({ }^{+37} \mathrm{C}_{3} \mathrm{H}^{+},{ }^{+39} \mathrm{C}_{3} \mathrm{H}_{3}{ }^{+}\right.$, and $\left.{ }^{+43} \mathrm{CH}_{3} \mathrm{CO}^{+}\right)$. Strong sulphate $\left({ }^{-97} \mathrm{HSO}_{4}{ }^{-}\right)$and nitrate $\left({ }^{-46} \mathrm{NO}_{2}^{-}\right.$and $\left.{ }^{-62} \mathrm{NO}_{3}{ }^{-}\right)$signals were identified in the negative ion mass spectra. The sizes of the ECOC particles were much larger than those of pure EC particles, indicating that ECOC particles are formed by EC particles after atmospheric ageing.

KEC particles mainly originate from biomass or coal burning (Moffet et al., 2008; Bi et al., 2011; Healy et al., 2012; Wang et al., 2013b; Gong et al., 2016; Li et al., 2018). The notable characteristic of KEC particles is that the positive ion mass spectra contain ${ }^{+39 / 41} \mathrm{~K}^{+}$and ${ }^{+213 / 215} \mathrm{~K}_{3} \mathrm{SO}_{4}{ }^{+}$signals (Silva et al., 1999; Hudson et al., 2004), whereas the negative ion mass spectra contain ${ }^{-26} \mathrm{CN}^{-}$and ${ }^{-42} \mathrm{CNO}^{-}$ signals. Levoglucosan fragments $\left({ }^{-71} \mathrm{C}_{3} \mathrm{H}_{3} \mathrm{O}_{2}^{-}\right.$and $\left.{ }^{-73} \mathrm{C}_{3} \mathrm{H}_{5} \mathrm{O}_{2}^{-}\right)$are also observed.

The NaKEC particles demonstrated EC fragment ions in both positive and negative ion mass spectra. Moreover, ${ }^{+23} \mathrm{Na}^{+}$and ${ }^{+39} \mathrm{~K}^{+}$and ${ }^{-97} \mathrm{HSO}_{4}{ }^{-}$and ${ }^{-46} \mathrm{NO}_{2}^{-}$and ${ }^{-62} \mathrm{NO}_{3}{ }^{-}$were present in the positive and negative ion mass spectra, respectively. According to the literature, these ions were likely emitted by diesel vehicles (Li et al., 2013; Li et al., 2017).

The Other category, comprising particles not belonging to the four aforementioned groups, included heavy metal, dust, ash, and sea-salt particles and accounted for $7.66 \%$ of BC-containing particle number. This type of particle was not the focus of this study. 


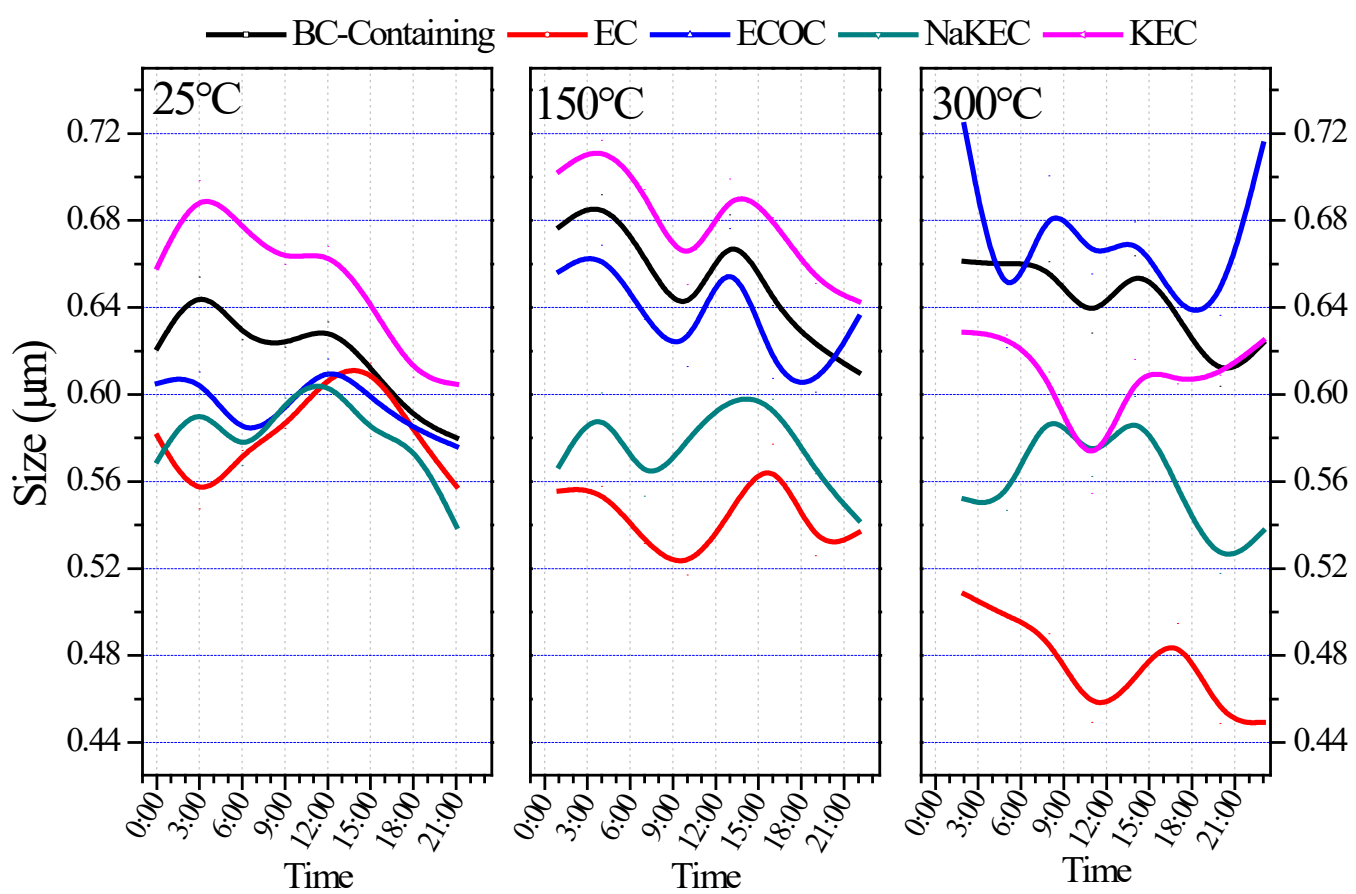

Fig. 4. Diurnal variation in BC-containing particle size.

\subsection{Mixing State and Size Distribution of Individual BC Particles}

\subsubsection{Diurnal variation in $\mathrm{BC}$ size distribution}

The diurnal variation in BC particle size, measured using SPAMS, is presented in Fig. 4. Notably, aerosols detected using SPAMS were mainly distributed between 400 and $1200 \mathrm{~nm}$, and detection efficiency decreased when the size became smaller than $400 \mathrm{~nm}$ and larger than $1200 \mathrm{~nm}$ (Li et al., 2011). As indicated in the figure, the BC aerosol size was related to the thermo-denuder heating temperature. The $\mathrm{BC}$ size was maximum at $150^{\circ} \mathrm{C}$. One reason for this may be that heating causes low-volatility components in the air to coat the BC surface, enlarging the entire particle. Another reason is that volatilisation of the surface components causes the reduction of sizes of some large BC aerosols, and they coincidentally fall within the SPAMS detection range. The diurnal variation in $\mathrm{BC}$-containing particles showed a bimodal distribution, with two peak values appearing at 3:00 and 12:00, which is attributable to the decrease in urban traffic emission in these two periods. The BC particles emitted by vehicles are smaller than those from other BC sources (Harris and Maricq, 2001; Zervas and Dorlhène, 2006; Xue et al., 2015). Many vehicles emit fresh BC particles during rush hour in both the morning and evening, resulting in clear valley values in BCcontaining particle sizes, which is consistent with the diurnal variation in the EC and NaKEC size distribution. Studies have indicated that EC and NaKEC mainly originate from motor vehicle emissions (Li et al., 2018; Li et al., 2021). The sizes of EC and NaKEC particles are significantly smaller than those of KEC and ECOC particles under the same temperatures, which is consistent with previous results (Li et al., 2018). The size of ECOC particles increased with an increase in the heating temperature. This may be because high temperatures cause some ECOC surface components to volatilise, leading to a decreased particle size that falls within the efficient detection range of SPAMS. The ECOC size at night was larger than that in the day at $300^{\circ} \mathrm{C}$, which differs from the diurnal change that occurred at $25^{\circ} \mathrm{C}$. However, the EC and NaKEC particle sizes decreased with an increase in temperature. This is because the volatile components on the surface escaped with volatilisation due to the high temperature, resulting in smaller particle sizes.

\subsubsection{Diurnal variation in $\mathrm{BC}$ chemical composition}

The diurnal variation in $\mathrm{BC}$ number concentrations identified using SPAMS is presented in Fig. 5. Generally, the maximum number concentrations for each category were attained at $150^{\circ} \mathrm{C}$, mainly due to the volatilisation of the surface components of large particles. This resulted in the particle 


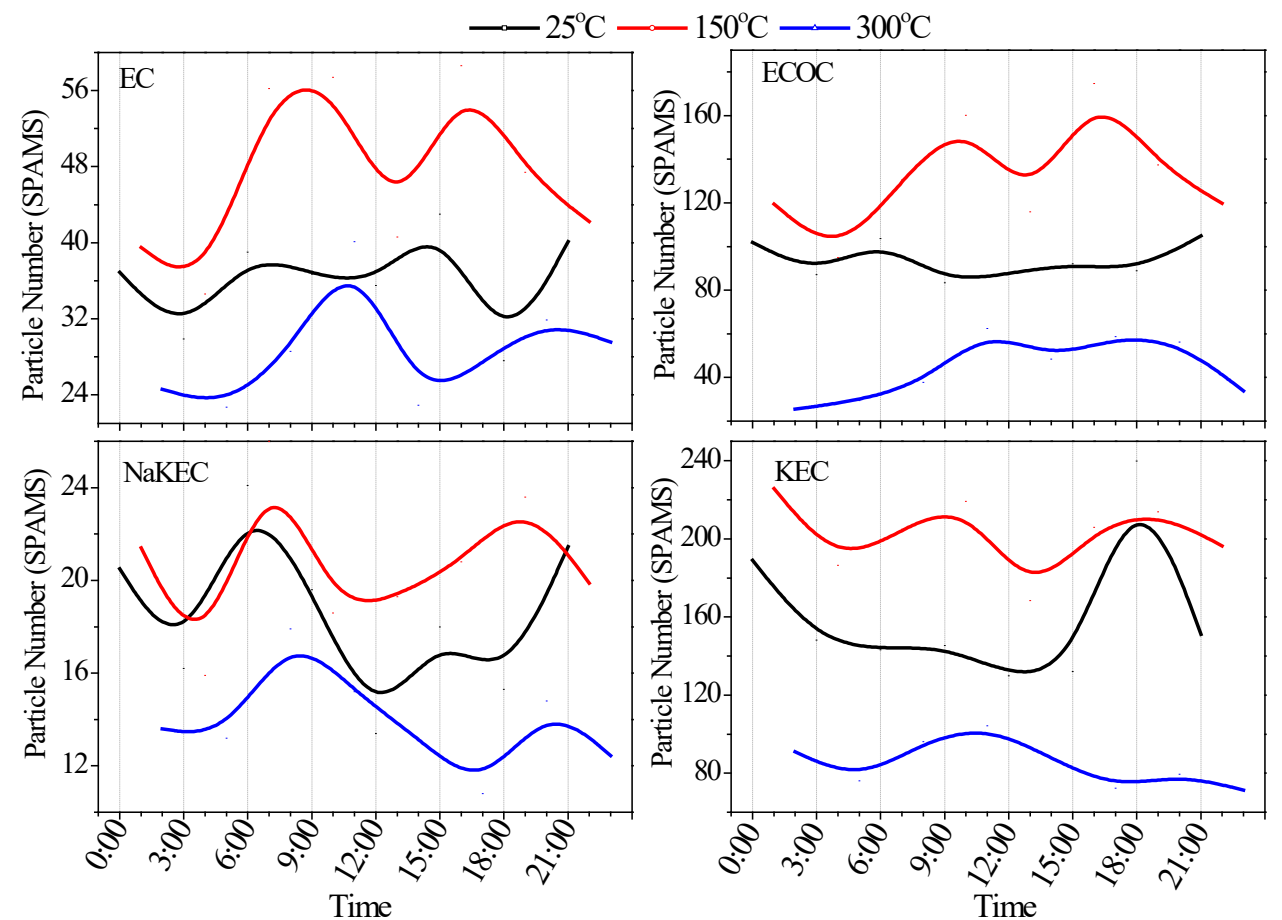

Fig. 5. Diurnal variation in $\mathrm{BC}$ particle number.

size decreasing and falling within the measurement range of SPAMS. At $300^{\circ} \mathrm{C}$, all of the volatile components on the $\mathrm{BC}$ surface volatilised, leading to a sharp decrease in $\mathrm{BC}$ size, which decreased to below the minimum detection range of SPAMS $(200 \mathrm{~nm})$. Therefore, at $300^{\circ} \mathrm{C}$, the $\mathrm{BC}$ number concentration was the lowest. At $25^{\circ} \mathrm{C}$, elevated EC and NaKEC number concentrations occurred at 7:00, which can be explained by the increase in traffic emissions during rush hour (Dreher and Harley, 1998; Allen et al., 1999; Bhugwant et al., 2000). Lower boundary layer heights in the early morning also enhanced this trend. Similar trends occurred at $150^{\circ} \mathrm{C}$ and $300^{\circ} \mathrm{C}$. The number of all types of $\mathrm{BC}$ was the lowest at $300^{\circ} \mathrm{C}$, which can be explained by the majority of $\mathrm{BC}$ sizes being much smaller than the SPAMS detection limit. At $25^{\circ} \mathrm{C}$, elevated KEC concentrations occurred at 18:00, which may be caused by the use of straw for cooking in rural areas around Shanghai in the evening. Favourable diffusion conditions, a higher daytime boundary layer, and a lower boundary layer at night are key factors that caused the KEC concentration to be higher at night than that during the day.

\subsubsection{Diurnal variation in BC core-shell structures}

The diurnal variation in average $\mathrm{BC}$ cores and coating thicknesses at different temperatures are displayed in Fig. 6 . The smallest core size and the thickest coating occurred in the TD at the lowest temperature. As the temperature increased, the coating decreased and the BC core size increased. The $\mathrm{BC}$ coating volatilised and escaped during the heating process, causing the coating to become thinner. In this experiment, particles of different sizes flowing into SP2 were not limited to enable the detection of BC particles from different sources. Because SP2 has an efficient size range of 70 to $600 \mathrm{~nm}$, most ambient BC particles below $200 \mathrm{~nm}$ can be collected using SP2. As indicated in Fig. 6 , the $\mathrm{BC}$ core size was inversely correlated with its coating thickness. This experiment used the average results of numerous $\mathrm{BC}$ particles, which were affected by the detection efficiency of the instruments. At $300^{\circ} \mathrm{C}$, the $\mathrm{BC}$ coating was thicker in the day than at night because of the different chemical compositions of the coating. The coating components were mainly secondary organic carbon generated by photo-oxidation in the daytime and secondary inorganic salts at night. The low volatility of secondary organic carbon prevents them from easily escaping. However, secondary inorganic salts are highly volatile and escaped completely from the BC surface when it was heated to $300^{\circ} \mathrm{C}$. This resulted in a thicker $\mathrm{BC}$ coating being observed during the day than at night at $300^{\circ} \mathrm{C}$. 


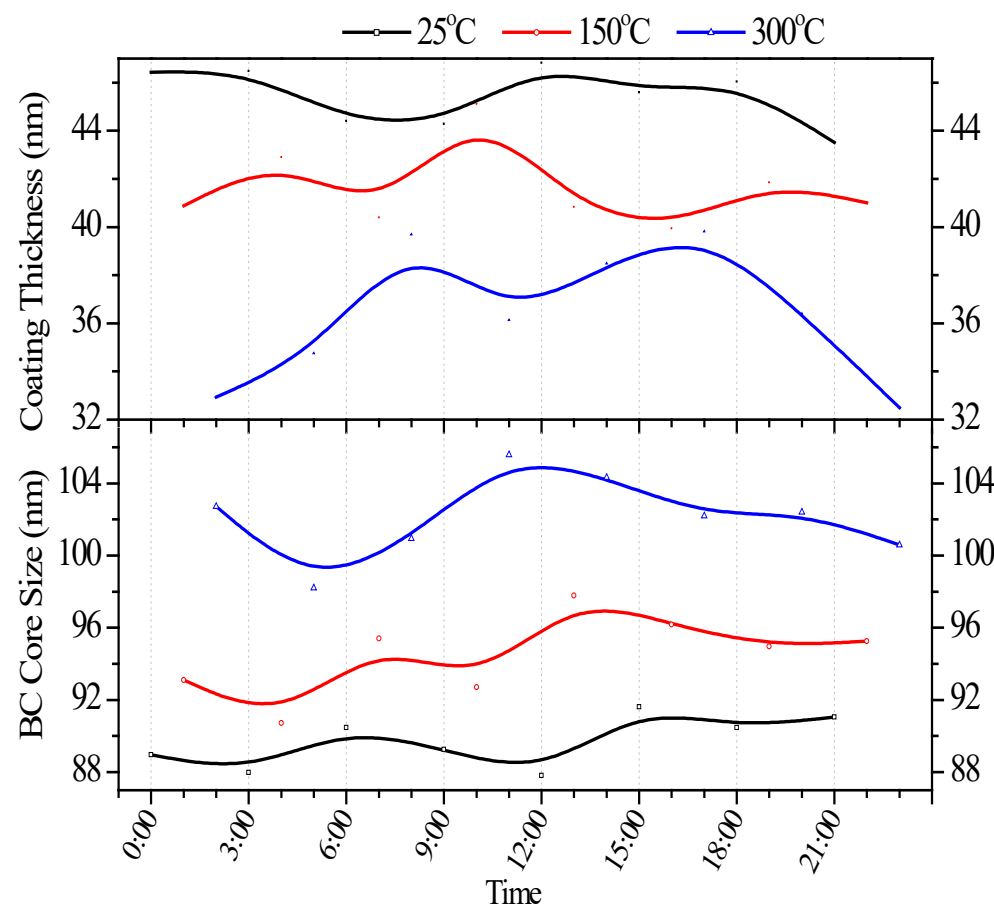

Fig. 6. Diurnal variation in $\mathrm{BC}$ core size and coating thickness.

\section{CONCLUSIONS}

In this study, a TD-SP2\&SPAMS system was applied to explore the effects of different volatile components on the mixing state and size distribution of ambient individual $\mathrm{BC}$ aerosols in Shanghai. Three temperatures $\left(25^{\circ} \mathrm{C}, 150^{\circ} \mathrm{C}\right.$, and $\left.300^{\circ} \mathrm{C}\right)$ were selected for observation of the diurnal variations in the $B C$ mixing state. The average mass spectra of five $B C$ types at three heating temperatures were compared. At room temperature, strong signals of nitrate and sulphate were observed in ECOC and KEC particles, suggesting that they were highly aged. After secondary components coated on $\mathrm{BC}$ surfaces volatilise, the residue on the $\mathrm{BC}$ core with a simplified mixing state can enable the identification of the primary source of $B C$ when heated using TD.

The results demonstrated that, at room temperature, $\mathrm{BC}$ mixes with other secondary substances, and the $\mathrm{BC}$ number fraction becomes low. At $300^{\circ} \mathrm{C}$, the secondary components volatilise, resulting in a thinner $\mathrm{BC}$ coating. Due to the decrease in the particle number and $\mathrm{BC}$ with low volatility at $300^{\circ} \mathrm{C}$, the $\mathrm{BC}$ number fraction increases to approximately $60 \%$, indicating the presence of some low-volatility non-BC substances, which may be secondary organic aerosols, potassium chloride, potassium nitrate, and other extremely low-volatility substances. This study demonstrated that atmospheric ageing considerably influences the $\mathrm{BC}$ mixing state. Information on diurnal variation in the $\mathrm{BC}$ mixing state and core-shell structure is essential to the evaluation of the ageing process, wet removal, and the climate effects of $\mathrm{BC}$ aerosol.

\section{ACKNOWLEDGMENTS}

Supports for the study from the National Natural Science Foundation of China (NSFC) under Grant Nos. NSFC-42167016, and the Key Research and Development Program of Ningxia Province in China (2020BEB04003) are much appreciated.

\section{SUPPLEMENTARY MATERIAL}

Supplementary material for this article can be found in the online version at https://doi. org/10.4209/aaqr.210400 


\section{REFERENCES}

Adler, G., Flores, J., Abo Riziq, A., Borrmann, S., Rudich, Y. (2011). Chemical, physical, and optical evolution of biomass burning aerosols: A case study. Atmos. Chem. Phys. 11, 1491-1503. https://doi.org/10.5194/acp-11-1491-2011

Allen, G.A., Lawrence, J., Koutrakis, P. (1999). Field validation of a semi-continuous method for aerosol black carbon (aethalometer) and temporal patterns of summertime hourly black carbon measurements in southwestern PA. Atmos. Environ. 33, 817-823. https://doi.org/ 10.1016/S1352-2310(98)00142-3

Bhugwant, C., Cachier, H., Bessafi, M., Leveau, J. (2000). Impact of traffic on black carbon aerosol concentration at la Reunion Island (Southern Indian Ocean). Atmos. Environ. 34, 3463-3473. https://doi.org/10.1016/S1352-2310(99)00405-7

Bi, X., Zhang, G., Li, L., Wang, X., Li, M., Sheng, G., Fu, J., Zhou, Z. (2011). Mixing state of biomass burning particles by single particle aerosol mass spectrometer in the urban area of PRD, China. Atmos. Environ. 45, 3447-3453. https://doi.org/10.1016/j.atmosenv.2011.03.034

Bond, T.C., Doherty, S.J., Fahey, D.W., Forster, P.M., Berntsen, T., DeAngelo, B.J., Flanner, M.G., Ghan, S., Kärcher, B., Koch, D. (2013). Bounding the role of black carbon in the climate system: A scientific assessment. J. Geophys. Res. 118, 5380-5552. https://doi.org/10.1002/jgrd.50171

Chirico, R., DeCarlo, P., Heringa, M., Tritscher, T., Richter, R., Prévôt, A., Dommen, J., Weingartner, E., Wehrle, G., Gysel, M. (2010). Impact of aftertreatment devices on primary emissions and secondary organic aerosol formation potential from in-use diesel vehicles: Results from smog chamber experiments. Atmos. Chem. Phys. 10, 11545-11563. https://doi.org/10.5194/acp-1011545-2010

Cre, A., Krecl, P. (2016). Local and regional contributions to black carbon aerosols in a mid-sized city in southern Brazil. Aerosol Air Qual. Res. 16, 125-137. https://doi.org/10.4209/aaqr. 2015.06.0388

Dreher, D.B., Harley, R.A. (1998). A fuel-based inventory for heavy-duty diesel truck emissions. J. Air Waste Manage. Assoc. 48, 352-358. https://doi.org/10.1080/10473289.1998.10463686

Engler, C., Rose, D., Wehner, B., Wiedensohler, A., Brüggemann, E., Gnauk, T., Spindler, G., Tuch, T., Birmili, W. (2007). Size distributions of non-volatile particle residuals $\left(D_{p}<800 \mathrm{~nm}\right)$ at a rural site in Germany and relation to air mass origin. Atmos. Chem. Phys. 7, 5785-5802. https://doi.org/10.5194/acp-7-5785-2007

Gong, X., Zhang, C., Chen, H., Nizkorodov, S.A., Chen, J., Yang, X. (2016). Size distribution and mixing state of black carbon particles during a heavy air pollution episode in Shanghai. Atmos. Chem. Phys. 16, 5399-5411. https://doi.org/10.5194/acp-16-5399-2016

Harris, S.J., Maricq, M.M. (2001). Signature size distributions for diesel and gasoline engine exhaust particulate matter. J. Aerosol Sci. 32, 749-764. https://doi.org/10.1016/S00218502(00)00111-7

Healy, R.M., Sciare, J., Poulain, L., Kamili, K., Merkel, M., Müller, T., Wiedensohler, A., Eckhardt, S., Stohl, A., Sarda-Estève, R. (2012). Sources and mixing state of size-resolved elemental carbon particles in a European megacity: Paris. Atmos. Chem. Phys. 12, 1681-1700. https://doi.org/ 10.5194/acp-12-1681-2012

Heringa, M.F., DeCarlo, P.F., Chirico, R., Tritscher, T., Dommen, J., Weingartner, E., Richter, R., Wehrle, G., Prévôt, A.S.H., Baltensperger, U. (2011). Investigations of primary and secondary particulate matter of different wood combustion appliances with a high-resolution time-offlight aerosol mass spectrometer. Atmos. Chem. Phys. 11, 5945-5957. https://doi.org/ 10.5194/acp-11-5945-2011

Huang, Y., Li, L., Li, J., Wang, X., Chen, H., Chen, J., Yang, X., Gross, D., Wang, H., Qiao, L. (2013). A case study of the highly time-resolved evolution of aerosol chemical and optical properties in urban Shanghai, China. Atmos. Chem. Phys. 13, 3931-3944. https://doi.org/10.5194/acp-133931-2013

Hudson, P.K., Murphy, D.M., Cziczo, D.J., Thomson, D.S., De Gouw, J.A., Warneke, C., Holloway, J., Jost, H.J., Hübler, G. (2004). Biomass-burning particle measurements: Characteristic composition and chemical processing. J. Geophys. Res. 109, D23. https://doi.org/10.1029/2003JD004398 Huffman, J.A., Ziemann, P.J., Jayne, J.T., Worsnop, D.R., Jimenez, J.L. (2008). Development and 
characterization of a fast-stepping/scanning thermodenuder for chemically-resolved aerosol volatility measurements. Aerosol Sci. Technol. 42, 395-407. https://doi.org/10.1080/0278682 0802104981

Huffman, J., Docherty, K., Mohr, C., Cubison, M., Ulbrich, I., Ziemann, P., Onasch, T., Jimenez, J. (2009). Chemically-resolved volatility measurements of organic aerosol from different sources. Environ. Sci. Technol. 43, 5351-5357. https://doi.org/10.1021/es803539d

Ishizaka, Y., Adhikari, M. (2003). Composition of cloud condensation nuclei. J. Geophys. Res. 108, D4. https://doi.org/10.1029/2002JD002085

Janssen, N.A., Hoek, G., Simic-Lawson, M., Fischer, P., Van Bree, L., Ten Brink, H., Keuken, M., Atkinson, R.W., Anderson, H.R., Brunekreef, B. (2011). Black carbon as an additional indicator of the adverse health effects of airborne particles compared with $\mathrm{PM}_{10}$ and $\mathrm{PM}_{2.5}$. Environ. Health Perspect. 119, 1691-1699. https://doi.org/10.1289/ehp.1003369

Jayne, J.T., Leard, D.C., Zhang, X., Davidovits, P., Smith, K.A., Kolb, C.E., Worsnop, D.R. (2000). Development of an aerosol mass spectrometer for size and composition analysis of submicron particles. Aerosol Sci. Technol. 33, 49-70. https://doi.org/10.1080/027868200410840

Johnson, G., Ristovski, Z., Morawska, L. (2004). Application of the VH-TDMA technique to coastal ambient aerosols. Geophys. Res. Lett. 31, L16105. https://doi.org/10.1029/2004GL020126

Jonsson, Å.M., Hallquist, M., Saathoff, H. (2007). Volatility of secondary organic aerosols from the ozone initiated oxidation of $\alpha$-pinene and limonene. J. Aerosol Sc. 38, 843-852. https://doi.org/ 10.1016/j.jaerosci.2007.06.008

Kanakidou, M., Seinfeld, J., Pandis, S., Barnes, I., Dentener, F.J., Facchini, M.C., Dingenen, R.V., Ervens, B., Nenes, A., Nielsen, C. (2005). Organic aerosol and global climate modelling: A review. Atmos. Chem. Phys. 5, 1053-1123. https://doi.org/10.5194/acp-5-1053-2005

Kondo, Y., Komazaki, Y., Miyazaki, Y., Moteki, N., Takegawa, N., Kodama, D., Deguchi, S., Nogami, M., Fukuda, M., Miyakawa, T. (2006). Temporal variations of elemental carbon in Tokyo. J. Geophys. Res. 111, D12. https://doi.org/10.1029/2005JD006257

Lelieveld, J., Berresheim, H., Borrmann, S., Crutzen, P., Dentener, F., Fischer, H., Feichter, J., Flatau, P., Heland, J., Holzinger, R. (2002). Global air pollution crossroads over the Mediterranean. Science 298, 794-799. https://doi.org/10.1126/science.1075457

Lelieveld, J., Pozzer, A., Pöschl, U., Fnais, M., Haines, A., Münzel, T. (2020). Loss of life expectancy from air pollution compared to other risk factors: A worldwide perspective. Cardiovasc. Res. 116, 1910-1917. https://doi.org/10.1093/cvr/cvaa025

Li, H., Zhang, Q., Zhang, Q., Chen, C., Wang, L., Wei, Z., Zhou, S., Parworth, C., Zheng, B., Canonaco, F. (2017). Wintertime aerosol chemistry and haze evolution in an extremely polluted city of the North China Plain: Significant contribution from coal and biomass combustion. Atmos. Chem. Phys. 17, 4751-4768. https://doi.org/10.5194/acp-17-4751-2017

Li, K., Ye, X., Pang, H., Lu, X., Chen, H., Wang, X., Yang, X., Chen, J., Chen, Y. (2018). Temporal variations in the hygroscopicity and mixing state of black carbon aerosols in a polluted megacity area. Atmos. Chem. Phys. 18, 15201-15218. https://doi.org/10.5194/acp-18-15201-2018

Li, K., Wang, X., Lu, X., Chen, H., Yang, X. (2021). Effect of pollution level on size distributions and mixing state of ambient black carbon particles in an urban area during wintertime. Aerosol Air Qual. Res. 21, 200655. https://doi.org/10.4209/aaqr.200655

Li, L., Huang, Z., Dong, J., Li, M., Gao, W., Nian, H., Fu, Z., Zhang, G., Bi, X., Cheng, P., Zhou, Z. (2011). Real time bipolar time-of-flight mass spectrometer for analyzing single aerosol particles. Int. J. Mass Spectrom. 303, 118-124. https://doi.org/10.1016/j.ijms.2011.01.017

Li, L., Tan, G., Zhang, L., Fu, Z., Nian, H., Huang, Z., Zhou, Z., Li, M. (2013). Analysis of diesel exhaust particles using single particle aerosol mass spectrometry. Chinese J. Anal. Chem. 41, 18311836. https://doi.org/10.3724/sp.j.1096.2013.30545

Liu, D., Allan, J., Whitehead, J., Young, D., Flynn, M., Coe, H., McFiggans, G., Fleming, Z.L., Bandy, B. (2013). Ambient black carbon particle hygroscopic properties controlled by mixing state and composition. Atmos. Chem. Phys. 13, 2015-2029. https://doi.org/10.5194/acp-13-2015-2013

Liu, J., Fan, S., Horowitz, L.W., Levy, H. (2011). Evaluation of factors controlling long-range transport of black carbon to the Arctic. J. Geophys. Res. 116, D04307. https://doi.org/ 10.1029/2010jd015145

Liu, S., Aiken, A.C., Gorkowski, K., Dubey, M.K., Cappa, C.D., Williams, L.R., Herndon, S.C., Massoli, P., Fortner, E.C., Chhabra, P.S. (2015). Enhanced light absorption by mixed source black and 
brown carbon particles in UK winter. Nat. Commun. 6, 8435. https://doi.org/10.1038/ ncomms9435

May, A.A., Saleh, R., Hennigan, C.J., Donahue, N.M., Robinson, A.L. (2012). Volatility of organic molecular markers used for source apportionment analysis: Measurements and implications for atmospheric lifetime. Environ. Sci. Technol. 46, 12435-12444. https://doi.org/10.1021/ es302276t

Meng, J., Liu, J., Guo, S., Li, J., Li, Z., Tao, S. (2016). Trend and driving forces of Beijing's black carbon emissions from sectoral perspectives. J. Cleaner Prod. 112, 1272-1281. https://doi.org/ 10.1016/j.jclepro.2015.05.027

Moffet, R.C., de Foy, B., Molina, L.T., Molina, M.J., Prather, K.A. (2008). Measurement of ambient aerosols in northern Mexico City by single particle mass spectrometry. Atmos. Chem. Phys. 8, 4499-4516. https://doi.org/10.5194/acp-8-4499-2008

Pratt, K., Murphy, S., Subramanian, R., DeMott, P., Kok, G., Campos, T., Rogers, D., Prenni, A., Heymsfield, A., Seinfeld, J. (2011). Flight-based chemical characterization of biomass burning aerosols within two prescribed burn smoke plumes. Atmos. Chem. Phys. 11, 12549-12565. https://doi.org/10.5194/acp-11-12549-2011

Pratt, K.A., Prather, K.A. (2009). Real-time, single-particle volatility, size, and chemical composition measurements of aged urban aerosols. Environ. Sci. Technol. 43, 8276-8282. https://doi.org/ 10.1021/es902002t

Pratt, K.A., Hatch, L.E., Prather, K.A. (2009). Seasonal volatility dependence of ambient particle phase amines. Environ. Sci. Technol. 43, 5276-5281. https://doi.org/10.1021/es803189n

Silva, P.J., Liu, D.Y., Noble, C.A., Prather, K.A. (1999). Size and chemical characterization of individual particles resulting from biomass burning of local Southern California species. Environ. Sci. Technol. 33, 3068-3076. https://doi.org/10.1021/es980544p

Song, X.H., Hopke, P.K., Fergenson, D.P., Prather, K.A. (1999). Classification of single particles analyzed by ATOFMS using an artificial neural network, ART-2A. Anal. Chem. 71, 860-865. https://doi.org/10.1021/ac9809682

Spencer, M.T., Shields, L.G., Prather, K.A. (2007). Simultaneous measurement of the effective density and chemical composition of ambient aerosol particles. Environ. Sci. Technol. 41, 13031309. https://doi.org/10.1021/es061425+

Wang, J., Lei, Y., Ning, M. (2018). Chinese model for improving air quality: An assessment of action plan of air pollution prevention and control. Environ. Prot. 46, 7-11. https://doi.10.14026/ j.cnki.0253-9705.2018.02.001

Wang, J., Liu, D., Ge, X., Wu, Y., Shen, F., Chen, M., Zhao, J., Xie, C., Wang, Q., Xu, W., Zhang, J., Hu, J., Allan, J., Joshi, R., Fu, P., Coe, H., Sun, Y. (2019). Characterization of black carbon-containing fine particles in Beijing during wintertime. Atmos. Chem. Phys. 19, 447-458, https://doi.org/ 10.5194/acp-19-447-2019

Wang, Q., Cao, J., Tao, J., Li, N., Su, X., Chen, L.W.A., Wang, P., Shen, Z., Liu, S., Dai, W. (2013). Longterm trends in visibility and at Chengdu, China. PLoS One 8, e68894. https://doi.org/10.1371/ journal.pone.0068894

Wang, Q., Huang, R.J., Cao, J., Han, Y., Wang, G., Li, G., Wang, Y., Dai, W., Zhang, R., Zhou, Y. (2014a). Mixing state of black carbon aerosol in a heavily polluted urban area of China: Implications for light absorption enhancement. Aerosol Sci. Technol. 48, 689-697. https://doi.org/10.1080/02786826.2014.917758

Wang, Q., Huang, R.J., Cao, J., Tie, X., Ni, H., Zhou, Y., Han, Y., Hu, T., Zhu, C., Feng, T. (2015). Black carbon aerosol in winter northeastern Qinghai-Tibetan Plateau, China: The source, mixing state and optical property. Atmos. Chem. Phys. 15, 13059-13069. https://doi.org/10.5194/acp15-13059-2015

Wang, X., Williams, B., Tang, Y., Huang, Y., Kong, L., Yang, X., Biswas, P. (2013b). Characterization of organic aerosol produced during pulverized coal combustion in a drop tube furnace. Atmos. Chem. Phys. 13, 10919-10932. https://doi.org/10.5194/acp-13-10919-2013

Wang, X., Ye, X., Chen, H., Chen, J., Yang, X., Gross, D.S. (2014b). Online hygroscopicity and chemical measurement of urban aerosol in Shanghai, China. Atmos. Environ. 95, 318-326. https://doi.org/10.1016/j.atmosenv.2014.06.051

Wang, Y., Pang, Y., Huang, J., Bi, L., Che, H., Zhang, X., Li, W. (2021). Constructing shapes and mixing structures of black carbon particles with applications to optical calculations. J. Geophys. Res. 
126, e2021JD034620. https://doi.org/10.1029/2021JD034620

Wu, Y., Wang, X., Tao, J., Huang, R., Tian, P., Cao, J., Zhang, L., Ho, K.F., Han, Z., Zhang, R. (2017). Size distribution and source of black carbon aerosol in urban Beijing during winter haze episodes. Atmos. Chem. Phys. 17, 7965-7975, https://doi.org/10.5194/acp-17-7965-2017

Xie, C., Xu, W., Wang, J., Liu, D., Ge, X., Zhang, Q., Wang, Q., Du, W., Zhao, J., Zhou, W. (2019). Light absorption enhancement of black carbon in urban Beijing in summer. Atmos. Environ. 213, 499-504. https://doi.org/10.1016/j.atmosenv.2019.06.041

Xue, J., Li, Y., Wang, X., Durbin, T.D., Johnson, K.C., Karavalakis, G., Asa-Awuku, A., Villela, M., Quiros, D., Hu, S. (2015). Comparison of vehicle exhaust particle size distributions measured by SMPS and EEPS during steady-state conditions. Aerosol Sci. Technol. 49, 984-996. https://doi.org/10.1080/02786826.2015.1088146

Zervas, E., Dorlhène, P. (2006). Comparison of exhaust particle number measured by EEPS, CPC, and ELPI. Aerosol Sci. Technol. 40, 977-984. https://doi.org/10.1080/02786820600844093

Zhai, J., Lu, X., Li, L., Zhang, Q., Zhang, C., Chen, H., Yang, X., Chen, J. (2017). Size-resolved chemical composition, effective density, and optical properties of biomass burning particles. Atmos. Chem. Phys. 17, 7481-7493. https://doi.org/10.5194/acp-17-7481-2017

Zhai, J., Wang, X., Li, J., Xu, T., Chen, H., Yang, X., Chen, J. (2015). Thermal desorption single particle mass spectrometry of ambient aerosol in Shanghai. Atmos. Environ. 123, 407-414. https://doi.org/10.1016/j.atmosenv.2015.09.001

Zhang, D., Zhang, R. (2005). Laboratory investigation of heterogeneous interaction of sulfuric acid with soot. Environ. Sci. Technol. 39, 5722-5728. https://doi.org/10.1021/es050372d

Zhang, R., Wang, G., Guo, S., Zamora, M.L., Ying, Q., Lin, Y., Wang, W., Hu, M., Wang, Y. (2015a). Formation of urban fine particulate matter. Chem. Rev. 115, 3803-3855. https://doi.org/ 10.1021/acs.chemrev.5b00067

Zhang, X.Y., Wang, J.Z., Wang, Y.Q., Liu, H.L., Sun, J.Y., Zhang, Y.M. (2015b). Changes in chemical components of aerosol particles in different haze regions in China from 2006 to 2013 and contribution of meteorological factors. Atmos. Chem. Phys. 15, 12935-12952. https://doi.org/ 10.5194/acp-15-12935-2015

Zhou, J., Zhang, R., Cao, J., Chow, J.C., Watson, J.G. (2012). Carbonaceous and ionic components of atmospheric fine particles in Beijing and their impact on atmospheric visibility. Aerosol Air Qual. Res. 12, 492-502. https://doi.org/10.4209/aaqr.2011.11.0218 